\title{
Analisa Tingkat Pengetahuan dan Sikap Mahasiswa Farmasi Tingkat Akhir terhadap Penyakit Diabetes mellitus
}

\author{
Rizka Novia Atmadani* \\ Dosen Program Studi Farmasi, Fakultas Ilmu Kesehatan, Universitas Muhammadiyah Malang, Malang, Indonesia \\ rizkanovia@umm.ac.id \\ *korespondensi penulis
}

\begin{tabular}{|c|c|}
\hline & \\
\hline Diterima : & \multirow{15}{*}{$\begin{array}{l}\text { Diabetes merupakan permasalahan sangat besar dan terus meningkat di tingkat global } \\
\text { dan diperkirakan meningkat menjadi sekitar } 642 \text { juta orang atau sekitar I diantara I0 } \\
\text { orang dewasa pada tahun 2040. Strategi yang efektif perlu dilakukan secara } \\
\text { terintegrasi dan menyeluruh dengan berbasiskan pada masyarakat dengan melakukan } \\
\text { kerjasama lintas program, lintas sektor, dan swasta (termasuk pada organisasi profesi } \\
\text { dan masyarakat). Untuk itu, pengendalian diabetes sedini mungkin diharapkan } \\
\text { menjadi salah satu cara untuk mengurangi prevalensi tingginya diabetes mellitus. } \\
\text { Termasuk dengan mengetahui tingkat pengetahuan calon tenaga kesehatan terhadap } \\
\text { penyakit diabetes yang kelak melakukan pelayanan langsung kepada pasien diabetes. } \\
\text { Tujuan dari penelitian ini adalah untuk mengetahui seberapa tinggi tingkat } \\
\text { pengetahuan para mahasiswa farmasi tingkat akhir sebuah Universitas yang nantinya } \\
\text { akan menjadi Apoteker yang memberikan edukasi kepada masyarakat terkait penyakit } \\
\text { Diabetes mellitus. Penelitian ini merupakan penelitian deskriptif dan alat } \\
\text { pengumpulan data yang digunakan yaitu kuesioner diberikan kepada } 55 \text { responden. } \\
\text { Hasil penelitian ini didapatkan kesimpulan bahwa tingkat pengetahuan mahasiswa } \\
\text { Farmasi tingkat akhir di sebuah Universitas ini termasuk baik dapat dilihat pada nilai } \\
\text { rata-rata yaitu } 7,55 \text { untuk pengetahuan umum, 3,89 untuk pengetahuan tentang } \\
\text { faktor risiko, dan 6,5I untuk pengetahuan tentang manajemen/pengobatan Diabetes } \\
\text { mellitus yang dimana nilai maksimal masing-masing sub bab adalah 8, } 4 \text {, dan } 7 \text {. }\end{array}$} \\
\hline & \\
\hline & \\
\hline & \\
\hline $\begin{array}{l}\text { Diset } \\
\text { I4-0 }\end{array}$ & \\
\hline & \\
\hline & \\
\hline & \\
\hline & \\
\hline & \\
\hline & \\
\hline & \\
\hline & \\
\hline & \\
\hline & \\
\hline
\end{tabular}

Key word:

Knowledge;

University students;

Diabetes Mellitus;

Pharmacy.

\section{ABSTRACT}

Diabetes is a very problematic disease and continues to arise at the global level and is estimated to increase around 642 million people or about I in I0 adults by 2040 . An effective strategy needs to be carried out in an integrated and comprehensive manner based on society by collaborating across programs, across sector, and the private sector (including professional and community organizations). Therefore, controlling diabetes as early as possible is expected to be one way to reduce the high prevalence of diabetes mellitus. This includes knowing the level of knowledge of potential health workers on diabetes who will provide direct services to diabetes patients. The purpose of this study was to determine how high the level of knowledge of the final year pharmacy students of a university who will later become pharmacists who provide education to the public regarding Diabetes Mellitus. This research is a descriptive study and the data collection tool used is a questionnaire given to 55 respondents. The results of this study concluded that the level of knowledge of the final year Pharmacy students at a University was good. It could be seen at the average score of 7.55 for general knowledge, 3.89 for knowledge of risk factors, and 6.5I for knowledge of management about Diabetes Mellitus therapy in which the maximum values for each of the sections are 8,4 , and 7 .

This is an open access article under the CC-BY-SA license. 


\section{Pendahuluan}

Menurut World Health Organization (WHO), Diabetes adalah penyakit metabolik kronis yang ditandai dengan peningkatan kadar glukosa darah (gula darah) yang meyebabkan kerusakan serius pada jantung pembuluh darah, mata, ginjal, dan saraf. Diabetes yang paling umum adalah diabetes tipe dua yang biasanya banyak terjadi pada orang dewasa. Hal ini terjadi ketika tubuh menjadi resisten terhadap insulin atau tidak menghasilkan cukup insulin. Dalam tiga dekade terakhir, prevalensi diabetes tipe dua telah meningkat secara dramatis di negara-negara dari seluruh tingkat pendapatan. Sedangkan, diabetes tipe I, yang dulu dikenal dengan nama Juvenile Diabetes atau diabetes yang tergantung pada insulin, adalah suatu kondisi kronis dimana pankreas memproduksi sedikit atau tidak ada insulin yang diproduksi secara alami oleh tubuh. Bagi orang yang hidup dengan diabetes, merupakan suatu hal yang penting untuk mendapatkan akses yang mudah dan terjangkau pada tempat perawatan yang layak termasuk mendapatkan insulin. Secara global, WHO telah menyepakati untuk bersama-sama menghentikan kenaikan prevalensi diabetes dan obesitas pada tahun 2025 (World Health Organization, 1999).

Diabetes merupakan permasalahan sangat besar dan terus meningkat di tingkat global dengan sejumlah 415 juta orang dewasa hidup dengan diabetes pada tahun 2015 dan diperkirakan meningkat menjadi sekitar 642 juta orang atau sekitar I diantara I0 orang dewasa pada tahun 2040. Banyak penyandang Diabetes tipe dua yang tidak menyadari kondisinya dalam kurun waktu cukup lama. Namun ketika mereka akhirnya menyadarinya, berbagai komplikasi serius kemungkina sudah berkembang. Jumlah orang dengan diabetes akan terus bertambah terutama menjadi isu serius pada negara low and middle income, hal ini menjadi ancaman terhadap pembangunan berkesinambungan.

WHO telah merekomendasikan bahwa strategi yang efektif perlu dilakukan secara terintegrasi dan menyeluruh dengan berbasiskan pada masyarakat dengan melakukan kerjasama lintas program, lintas sektor, dan swasta (termasuk pada organisasi profesi dan masyarakat) (World Health Organization (WHO), 2000). Menurut Panduan Pelaksanaan Hari Diabetes Sedunia 2016 (Kemenkes RI, 2016) menyebutkan bahwa perlu strategi dengan melibatkan semua penyedia layanan kesehatan untuk ikut dalam program pengendalian diabetes yang berkualitas. Untuk itu, pengendalian diabetes sedini mungkin diharapkan menjadi salah satu cara untuk mengurangi prevalensi tingginya diabetes mellitus. Termasuk dengan mengetahui tingkat pengetahuan calon tenaga kesehatan terhadap penyakit diabetes yang kelak melakukan pelayanan langsung kepada pasien diabetes.

Sebuah penelitian dengan judul "The knowledge attitude and practice regarding diabetes and diabetic retinopathy among the final yeat medical students of King Faisal University Medical College of Al Hasa region of Saudi Arabia: A cross sectional survey" yang dilakukan di Saudi Arabia (AlWadaani, 2013) menyebutkan bahwa siswa laki-laki mendapatkan skor yang lebih baik dalam tingkat pengetahuan dan praktik. Sedangkan pada skor sikap dari siswa perempuan signifikan lebih tinggi daripada siswa laki-laki. Kelemahan utama dari segi pengetahuan adalah tentang epidemiologi Diabetes mellitus (DM), tindak lanjut dari pasien diabetes untuk skrining retinopati diabetik dan hubungan lamanya diabetes dengan perkembangan dan perkembangan retinopati diabetik. Banyak siswa percaya bahwa diabetes lebih umum di antara orangorang yang tidak berpendidikan. Sembilan persen siswa tidak tahu sudut injeksi insulin yang tepat (A1Wadaani, 2013).

\section{Metode}

Waktu dan Tempat Peneliatian

Penelitian dilakukan pada bulan Juli sampai Agustus 2020 pada mahasiswa Program Studi Farmasi semester tujuh di Universitas Muhammadiyah Malang.

\section{Jenis Penelitian}

Pada penelitian ini digunakan desain penelitian cross-sectional (potong lintang) dengan memberikan kuesioner kepada partisipan untuk mengkaji tingkat pengetahuan dan sikap mahasiswa terhadap pengetahuan penyakit Diabetes mellitus.

\section{Alat dan Bahan}

Alat

Alat yang digunakan pada penelitian ini adalah lembar kuesioner yang dicantumkan melalui sebuah website secara online.

Bahan

Data pada penelitian ini berupa data primer yang diperoleh dari hasil kuesioner online yang diisi oleh responden.

\section{Populasi Penelitian}

Populasi dalam penelitian ini adalah seluruh mahasiswa tingkat akhir yaitu mahasiswa pada Program Studi Farmasi semester tujuh yang sedang menyelesaikan skripsi. 


\section{Sampel Penelitian}

Sampel yang digunakan pada penelitian ini adalah mahasiswa tingkat akhir pada Program Studi Farmasi di Universitas Muhammadiyah Malang yang memenuhi kriteria inklusi dan eksklusi yang diterapkan oleh Peneliti.

a. Kriteria inklusi :

I. Mahasiswa semester tujuh yang sedang mengerjakan skripsi

2. Mahasiswa yang berusia I8 tahun keatas.

3. Mahasiswa yang bersedia mengikuti penelitian dan mengisi kuesioner online.

b. Kriteria eksklusi :

I. Mahasiswa yang tidak aktif pada sistem perkuliahan semester tujuh.

Teknik sampling yang digunakan pada penelitian ini adalah teknik sampling convenience sampling.

\section{Instrumen Penelitian}

Penelitian ini menggunakan lembar kuesioner dari literatur-literatur yang berhubungan dengan penelitian jenis ini. Kuesioner mengandung beberapa pertanyaan yang mengkaji tingkat pengetahuan dan sikap mahasiswa terhadap penyakit Diabetes mellitus serta tentang data demografi responden. Pertanyaan-pertanyaan tentang Diabetes mellitus terbagi menjadi 2 sesi yaitu pertama adalah skala sikap dan kedua adalah tingkat pengetahuan. Kuesioner sikap dan tingkat pengetahuan diadaptasi dari sebuah judul penelitian yang ada di Singapura (Ho \& Li, 20I4) dimana satu tabel berisikan beberapa pernyataan untuk skala sikap dan ada tiga tabel yang berisikan beberapa pertanyaan untuk mengakses tingkat pengetahuan responden. Satu tabel lainnya adalah untuk menanyakan data demografik responden.

\section{Analisa Data}

Analisa data yang akan dilakukan yaitu analisa deskriptif berupa presentase hasil dari pertanyaan yang diajukan pada lembar kuesioner mulai dari data demografik, skala sikap, dan tingkat pengetahuan.

Pengumpulan data menggunakan kuesioner skala sikap dan tingkat pengetahuan. Semua jawaban dari skala sikap diberi skor berdasarkan skala Likert dengan tingkat penilaian sebagai berikut :

I. Tidak setuju $=$ I

2. Netral $=2$

3. Setuju $=3$

Sedangkan untuk tingkat pengetahuan juga menggunakan skala Likert dengan tingkat penilaian sebagai berikut :

I. $B$ enar $=\mathrm{I}$
2. Salah $=2$

3. Tidak tahu $=0$

Seluruh data dilakukan analisa dengan menggunakan software SPSS versi ke I8.

\section{Hasil dan Pembahasan}

Data Demografik Responden

Hasil penelitian ini, dari kuesioner online yang diberikan kepada mahasiswa Farmasi angkatan akhir di Universitas Muhammadiyah Malang, 55 mahasiswa setuju untuk ikut serta dalam penelitian ini dan mengisi kuesioner yang diberikan secara online. Dari 55 mahasiswa yang setuju ikut dalam penelitian ini, 83,6 adalah berjenis kelamin laki-laki, dan I6,4 adalah perempuan. Karakteristik demografik terpajang pada tabel hasil I. Berdasarkan tabel I, sebagian besar persentase memberikan keterangan bahwa responden tinggal di indekos $(76,4)$, berasal dari pedesaan $(52,7)$, tinggal sendirian (36,4), memiliki uang saku Rp 500.000 sampai Rp I.000.000 (4I,8), jarak tempat tinggal yang ditempati adalah $<\mathrm{I} \mathrm{km}(54,5)$, kondisi kesehatan sangat baik (49,I), tidak sedang bekerja $(94,5)$, dan tidak memiliki riwayat Penyakit Diabetes $(54,5)$.

\section{Skala Sikap Responden}

Hasil skala sikap dari 55 responden yang didapatkan adalah sebagian persentase menunjukkan bahwa 60 responden tidak setuju terhadap pernyataan 'Lebih banyak orang yang tidak berpendidikan dapat menderita diabetes dibandingkan yang berpendidikan'. 47,3 dari responden mengatakan setuju terhadap pernyataan 'Selama penyakit diabetes yang diderita tersebut terkontrol, tidak perlu khawatir terhadap adanya komplikasi'. Kemudian, sebanyak 58,2 dari 55 responden berpendapat setuju bahwa 'Jika penyakit diabetes diatasi lebih awal, diabetes retinopati dapat dicegah/ditunda'. Terakhir, dari skala sikap menunjukkan bahwa 54,5 responden bersikap netral terhadap pernyataan 'Semua pasien diabetes harus diperiksakan kepada dokter spesialis mata untuk pemeriksaan mata secara rutin. 
Tabel I. Karakteristik demografik responden

\begin{tabular}{|c|c|c|}
\hline \multirow[t]{2}{*}{ Karakteristik } & \multicolumn{2}{|c|}{ Total } \\
\hline & $\mathrm{n}$ & $(\%)$ \\
\hline \multicolumn{3}{|l|}{ Jenis Kelamin } \\
\hline Laki-laki & 9 & 16,4 \\
\hline Perempuan & 46 & 83,6 \\
\hline \multicolumn{3}{|l|}{ Tempat Tinggal } \\
\hline Kos & 46 & 76,4 \\
\hline Kontrakan & 50 & 3,6 \\
\hline Rumah Orang Tua & II & 20 \\
\hline \multicolumn{3}{|l|}{ Asal } \\
\hline Perkotaan & 26 & 47,3 \\
\hline Pedesaan & 29 & 52,7 \\
\hline \multicolumn{3}{|l|}{ Uang Saku } \\
\hline$<$ Rp. 500.000 & 5 & $9, \mathrm{I}$ \\
\hline Rp.500.000-Rp. & 23 & $4 \mathrm{I}, 8$ \\
\hline \multicolumn{3}{|l|}{$\begin{array}{l}\text { I.000.000 } \\
\text { I. }\end{array}$} \\
\hline Rp.I.I00.000-Rp. & 19 & 34,5 \\
\hline \multicolumn{3}{|l|}{2.000 .000} \\
\hline$>$ Rp. 2.000 .000 & 8 & $\mathrm{I} 4,5$ \\
\hline \multicolumn{3}{|l|}{ Jarak Rumah } \\
\hline$<\mathrm{I} \mathrm{km}$ & 30 & 54,5 \\
\hline $\mathrm{I} \mathrm{km}-2 \mathrm{~km}$ & 19 & 34,5 \\
\hline $2.1 \mathrm{~km}-3 \mathrm{~km}$ & 3 & 5,5 \\
\hline$>3 \mathrm{~km}$ & 3 & 5,5 \\
\hline \multicolumn{3}{|l|}{ Bekerja } \\
\hline $\mathrm{Ya}$ & 3 & 5,5 \\
\hline Tidak & 52 & 94,5 \\
\hline \multicolumn{3}{|l|}{ Kondisi Kesehatan } \\
\hline Sangat Baik & 27 & $49, \mathrm{I}$ \\
\hline Baik & 26 & 47,3 \\
\hline Cukupan & 2 & 3,6 \\
\hline Buruk & 0 & 0 \\
\hline Sangat Buruk & 0 & 0 \\
\hline \multicolumn{3}{|l|}{ Riwayat Diabetes } \\
\hline Ada & 25 & 45,5 \\
\hline Tidak & 30 & 54,5 \\
\hline
\end{tabular}

Tingkat Pengetahuan responden terhadap penyakit

\section{Diabetes mellitus}

Hasil dari tingkat pengetahuan responden tertera pada tabel 3 sampai tabel 6. Tabel 3 menunjukkan tingkat pengetahuan responden secara umum. Tabel 4 adalah tingkat pengetahuan terhadap faktor risiko penyakit Diabetes mellitus. Tabel 5 adalah informasi terkait tingkat pengetahuan responden pada terapi atau manajemen Diabetes mellitus. Dan tabel 6 adalah tabel yang menunjukkan skor dari masing-masing sub-bab pada bagian Pengetahuan.

\section{Tingkat Pengetahuan Secara Umum}

Hasil dari kuesioner pengetahuan secara umum tentang Diabetes mellitus pada mahasiswa tingkat akhir di Universitas Muhammadiyah Malang ini menunjukkan bahwa sebagian besar responden dapat menjawab dengan baik. Jika ditotal, hasil yang kemungkinan dapat diraih secara maksimal adalah 9. Dan berdasarkan tabel 6 , nilai tengah (median) yang didapat adalah 8 dengan nilai rata-rata 7,55. Jika dirunut dari masing-masing pernyataan yang ada pada kuesioner, pernyataan 'Tipe diabetes ada dua' adalah pernyataan yang memiliki persentase paling besar yang responden salah menjawabnya. Hal ini hampir serupa dengan penelitian yang ada pada Singapura (Ho \& Li, 20I4), dimana sebagian besar respondennya menjawab tidak tahu terhadap pertanyaan 'How many types of diabetes are there?. Banyak responden yang masih bingung terhadap tipe pernyataan seperti ini karena banyak tipe lain dari diabetes. Misalnya Diabetes Gestasional yang terjadi pada saat kehamilan saja (B et al., 2017). Sebagian responden yang menjawab salah dan tidak tahu, kemungkinan karena kebanyakan hanya mengetahuai tentang tipe Diabetes yang ada dua yang banyak terjadi di Masyarakat yaitu Diabetes tipe I dan 2.

Hasil dari jawaban responden yang paling banyak benar dijawab adalah pada pernyataan 'Diabetes adalah kondisi dimana terjadi kenaikan gula darah. Hal ini juga searah dengan penelitian yang ada di Singapura dimana paling banyak benar adalah pada tipe pernyataan tentang definisi Diabetes tersebut (Ho \& Li, 20I4).

\section{Tingkat Pengetahuan tentang Faktor Risiko}

Berdasarkan hasil dari jawaban responden pada sub-bab pengetahuan tentang faktor risiko, dapat dilihat pada tabel 4 dan tabel 6 dimana pada tabel 4 dapat diketahui bahwa hampir di semua pernyataan, responden dapat menjawab benar adalah $\geq 80 \%$. Dan pada tabel 6 dapat dilihat bahwa skor maksimal yang dapat dicapai adalah 5, dengan median 4, dan nilai rata-rata 3,89. Hal ini dapat ditarik kesimpulan bahwa responden sebagian besar telah memahami apa saja faktor risiko dari Diabetes mellitus yang dapat diwaspadai. Dari berbagai pernyataan yang ada pada kuesioner, pernyataan yang paling banyak benarnya adalah pada pernyataan 'obesitas' dan yang paling banyak salah adalah pada pernyataan 'diatas 40 tahun'. 
Tabel 2. Sikap Mahasiswa

\begin{tabular}{lccc}
\hline Pertanyaan & Tidak Setuju (\%) & Netral (\%) & Setuju (\%) \\
\hline $\begin{array}{l}\text { Lebih banyak orang yang tidak } \\
\text { berpendidikan dapat menderita diabetes } \\
\text { dibandingkan yang berpendidikan }\end{array}$ & $60 \%$ & $30,9 \%$ & $9,1 \%$ \\
\hline $\begin{array}{l}\text { Selama penyakit diabetes yang diderita } \\
\text { tersebut terkontrol, tidak perlu khawatir } \\
\text { terhadap adanya komplikasi }\end{array}$ & $20 \%$ & $32,7 \%$ & $47,3 \%$ \\
\hline $\begin{array}{l}\text { Jika penyakit diabetes diatasi lebih awal, } \\
\text { diabetes retinopati dapat } \\
\text { dicegah/ditunda }\end{array}$ & $12,7 \%$ & $29,1 \%$ & $58,2 \%$ \\
$\begin{array}{l}\text { Semua pasien diabetes harus } \\
\text { diperiksakan kepada dokter spesialis } \\
\text { mata untuk pemeriksan mata secara } \\
\text { rutin }\end{array}$ & $\mathrm{I} 8,2 \%$ & $54,5 \%$ & $27,3 \%$ \\
\hline
\end{tabular}

Tabel 3. Tingkat Pengetahuan Mahasiswa Secara Umum

\begin{tabular}{lccc}
\hline Pertanyaan & Benar (\%) & Salah (\%) & Tidak Tahu (\%) \\
\hline $\begin{array}{l}\text { Diabetes adalah kondisi dimana ada kenaikan } \\
\text { gula darah }\end{array}$ & $98,2 \%$ & $\mathrm{I}, 8 \%$ & $0 \%$ \\
\hline $\begin{array}{l}\text { Diabetes adalah kondisi dari ketidakcukupan } \\
\text { insulin }\end{array}$ & $87,3 \%$ & $\mathrm{I} 2,7 \%$ & $0 \%$ \\
\hline $\begin{array}{l}\text { Diabetes adalah kondisi dari tubuh yang } \\
\text { tidak respon terhadap insulin }\end{array}$ & $78,2 \%$ & $\mathrm{I} \%, 4 \%$ & $5,5 \%$ \\
\hline $\begin{array}{l}\text { Diabetes itu tidak menular } \\
\text { Tipe Diabetes ada 2 macam }\end{array}$ & $85,5 \%$ & $\mathrm{I} \%, 5 \%$ & $0 \%$ \\
Diabetes itu tidak dapat disembuhkan & $58,2 \%$ & $41,8 \%$ & $0 \%$ \\
\hline Insulin adalah sebuah hormone & $83,6 \%$ & $\mathrm{I} 6,4 \%$ & $0 \%$ \\
\hline Insulin dapat mengontrol gula darah & $90,6 \%$ & $5,5 \%$ & $3,6 \%$ \\
\hline $\begin{array}{l}\text { Insulin itu dibutuhkan/diperlukan oleh } \\
\text { beberapa pasien diabetes }\end{array}$ & $94,5 \%$ & $5,5 \%$ & $0 \%$ \\
\hline
\end{tabular}

Sebagian besar responden berarti paham bahwa menjadi obesitas adalah salah satu faktor risiko yang paling banyak terjadi menyebabkan Diabetes mellitus. Dan apabila seseorang diatas 40 tahun, sebagian responden tidak tahu bahwa usia diatas 40 tahun adalah faktor risiko yang dominan pada DM tipe 2 saja (Trisnawati \& Setyorogo, 2013). Sedangkan Diabetes tipe I karena defisiensi insulin banyak juga terjadi pada anak-anak.

\section{Tingkat pengetahuan tentang manajemen Diabetes} / Pengobatannya

Hasil dari tingkat pengetahuan responden tentang manajemen Diabetes/pengobatannya terpapar pada tabel hasil 5. Berdasarkan jawaban dari responden, menunjukkan bahwa tingkat pengetahuan responden terhadap manajemen Diabetes adalah mencapai skor yang paling baik dibandingkan dengan tingkat pengetahuan dari sub-bab yang lain. Hal ini ditunjukkan dari persentase jawaban benar yang dijawab oleh hampir seluruh responden pada tabel 5 yang menunjukkan lebih dari $90 \%$. Berdasarkan tabel 5 juga dapat diketahui bahwa pada dua item pernyataan, responden dapat menjawab benar keseluruhannya yaitu I00\%. Jika dilihat berdasarkan tabel 6, nilai maksimal yang dapat dicapai adalah 7 , dengan mediannya 7 , dan nilai rata-rata 6,5 . 
Tabel 4. Pengetahuan Tentang Faktor Risiko

\begin{tabular}{lccc}
\hline Pertanyaan & Benar (\%) & Salah (\%) & Tidak Tahu (\%) \\
\hline $\begin{array}{l}\text { Karena adalanya riwayat keluarga yang } \\
\text { memiliki penyakit Diabetes }\end{array}$ & $92,7 \%$ & $7,3 \%$ & $0 \%$ \\
\hline Usia diatas 40 tahun & $80 \%$ & $20 \%$ & $0 \%$ \\
\hline Obesitas & $100 \%$ & $0 \%$ & $0 \%$ \\
\hline Kehamilan & $80 \%$ & $16,4 \%$ & $3,6 \%$ \\
\hline Suka makanan manis dan tidak sehat & $96,4 \%$ & $1,8 \%$ & $1,8 \%$ \\
\hline
\end{tabular}

Tabel 5. Pengetahuan Tentang Manajemen Diabetes/ Pengobatannya

\begin{tabular}{|c|c|c|c|}
\hline Pertanyaan & Benar (\%) & Salah (\%) & Tidak Tahu (\%) \\
\hline \multicolumn{4}{|l|}{ Obat yang tersedia } \\
\hline $\begin{array}{l}\text { Injeksi insulin tersedia untuk } \\
\text { mengontrol diabetes }\end{array}$ & $98,2 \%$ & $\mathrm{I}, 8 \%$ & $0 \%$ \\
\hline $\begin{array}{l}\text { Tablet dan kapsul (OAD) tersedia } \\
\text { untuk mengontrol diabetes }\end{array}$ & $100 \%$ & $0 \%$ & $0 \%$ \\
\hline \multicolumn{4}{|l|}{ Pola Hidup dan Ukuran Non farmakologi } \\
\hline $\begin{array}{l}\text { Pasien diabetes harus membawa gula } \\
\text { / makanan manis ketika mereka } \\
\text { keluar / berpergian }\end{array}$ & $72,7 \%$ & $23,6 \%$ & $3,6 \%$ \\
\hline $\begin{array}{l}\text { Pasien diabetes harus berolahraga } \\
\text { secara rutin dan reguler }\end{array}$ & $89,1 \%$ & $9,1 \%$ & $\mathrm{I}, 8 \%$ \\
\hline $\begin{array}{l}\text { Pasien diabetes harus mengontrol } \\
\text { berat badannya }\end{array}$ & $100 \%$ & $0 \%$ & $0 \%$ \\
\hline $\begin{array}{l}\text { Pasien deiabetes harus mengecek } \\
\text { secara reguler kondisi matanya }\end{array}$ & $94,5 \%$ & $3,6 \%$ & $\mathrm{I}, 8 \%$ \\
\hline $\begin{array}{l}\text { Pasien diabetes harus memiliki kadar } \\
\text { lemak yang rendah dan kadar } \\
\text { makanan sehat yang tinggi serat }\end{array}$ & $96,4 \%$ & $3,6 \%$ & $0 \%$ \\
\hline
\end{tabular}

Tabel 6. Skor maksimal, nilai rata-rata, standar deviasi, dan mode dari masing-masing bagian pengetahuan

\begin{tabular}{lccccc}
\hline \multicolumn{1}{c}{ Bagian } & $\begin{array}{l}\text { Skor } \\
\text { Maksimal }\end{array}$ & Median & $\begin{array}{l}\text { Standar } \\
\text { Deviasi (SD) }\end{array}$ & Nilai rata-rata & Mode \\
\hline Pengetahuan Umum & 9 & 8 & $\mathrm{I}, \mathrm{I0}$ & 7,55 & 8 \\
\hline Faktor Risiko & 5 & 4 & 0,60 & 3,89 & 4 \\
\hline Manajemen/Pengobatan & 7 & 7 & 0,77 & $6,5 \mathrm{I}$ & 7 \\
\hline
\end{tabular}

Hal ini menunjukkan bahwa jawaban dari responden pada nilai rata-rata adalah hampir mencapai nilai maksimal. Seragam dengan penelitian yang dilakukan oleh Wee et al, tingkat pengetahuan responden pada bidang manajemen pengobatan ini adalah sesi yang paling baik skornya (Ho \& Li, 20I4). Sangat menarik sekali mengetahui hasil tersebut karena melihat bahwa responden adalah mahasiswa yang sedang menempuh kuliah kefarmasian dan sedang pada semester akhir. Hal ini menandakan mahasiswa farmasi ini telah siap terjun pada masyarakat dan memberikan edukasi terkait pengobatan Diabetes mellitus.

Persentase tertinggi pada bagian ini adalah pada pernyataan 'Tablet dan kapsul (OAD) tersedia untuk mengontrol diabetes' dan 'Pasien diabetes harus mengontrol berat badannya' dimana 100\% responden benar menjawabnya. Sedangkan yang terendah adalah pada pernyataan 'Pasien diabetes harus membawa gula/makanan manis ketika mereka keluar/berpergian. Hal ini menandakan bahwa responden harus lebih memahami terkait risiko yang dapat terjadi jika terjadi hipoglikemi pada pasien Diabetes mellitus. Dengan membawa gula atau makanan manis dapat membantu mengatasi masalah hipoglikemi tersebut.

\section{Skor Setiap Sub-bab Pengetahuan}

Dari data tersebut kemudian dianalisa lebih lanjut dengan menilai pada persentase nilai atau skor yang benar dari masing-masing sub-bab (Tabel 3 
sampai Tabel 6). Dari tabel 6 tersebut dapat dilihat bahwa masing-masing sub-bab pengetahuan memiliki nilai maksimal, median, nilai rata-rata, standar deviasi, dan mode. Berdasarkan tabel 6 skor 9 adalah skor maksimal untuk sub-bab pengetahuan

secara umum, Skor 5 adalah untuk nilai maksimal pada sub-bab pengetahuan tentang faktor risiko, dan skor 7 adalah nilai maksimal pada sub-bab pengetahuan tentang manajemen atau pengobatan.

\section{Simpulan dan Saran}

Berdasarkan penelitian yang dilakukan, maka nilai dari masing-masing bab untuk pengetahuan tentang Diabetes mellitus diantara para mahasiswa Farmasi tingkat akhir Universitas Muhammadiyah Malang hampir mencapai nilai maksimal dimana dapat dilihat pada nilai rata-rata yaitu 7,55 untuk pengetahuan umum, 3,89 untuk pengetahuan tentang faktor risiko, dan 6,5I untuk pengetahuan tentang manajemen/pengobatan Diabetes mellitus.

Bagi peneliti selanjutnya dapat dilakukan penelitian untuk mecari faktor-faktor yang berhubungan dengan tingkat pengetahuan pada mahasiswa Farmasi terkait penyakit lainnya.

\section{Ucapan Terima Kasih}

Ucapan terima kasih saya sampaikan kepada para mahasiswa Farmasi di Universitas Muhammadiyah Malang yang telah bersedia mengikuti penelitian ini hingga selesai.

\section{Daftar Pustaka}

Al-Wadaani, F. A. (2013). The knowledge attitude and practice regarding diabetes and diabetic retinopathy among the final year medical students of King Faisal University Medical College of Al Hasa region of Saudi Arabia: A cross sectional survey. Nigerian Journal of Clinical Practice, I6(2), I64-I68. https://doi.org/I0.4103/I I I93077.I I0I33

B, H. P., Nurshanty, A., \& Sasiarini, L. (2017). Keterlambatan Diagnosis Diabetes Mellitus pada Kehamilan Late Diagnosis of Diabetes Mellitus in Pregnancy. Jurnal Kedokteran Brawijaya, 29(3), 28I-285.

Ho, H. K., \& Li, S. C. (2014). Public Awareness of Diabetes Mellitus in Singapore.

Kemenkes RI. (2016). Panduan Pelaksanaan Hari Diabetes Sedunia.

Trisnawati, S. K., \& Setyorogo, S. (2013). Faktor

\footnotetext{
Risiko Kejadian Diabetes Melitus Tipe II
}

Di Puskesmas Kecamatan Cengkareng Jakarta Barat Tahun 2012. Jurnal Ilmiah Kesehatan, 5(I), 6-II.

World Health Organization. (1999). Department of Noncommunicable Disease Surveillance Geneva. Definition, Diagnosis and Classification of Diabetes Mellitus and its Complications.

World Health Organization (WHO). (2000). Consultation report. 